\title{
Textbooks as a basic resource for the promotion of intercultural coexistence? - A case study
}

\author{
Susana Amante, Sara Pinho and João Paulo Balula
}

\begin{abstract}
It has become commonplace to assert that we are living in a time of rapid economic transformation and social mobilisation, which leads to a massive flow of people and goods across borders. This phenomenon has been changing the way in which communities function and, besides economic and social implications, political and cultural conditions follow a parallel course. No longer, if ever, can we speak of "pure" cultures rooted in one particular geography, because cross-cultural interactions have been challenging one's sense of identity. As a matter of fact, identities are hybrid, dynamic, often fractured and even imagined in nature. Yet, certain common experiences and phenotypical traits have contributed, most of the times, to the emergence of a national consciousness and to an ethnocentric/eurocentred vision of the world.

Cliché as this may sound, since there is now a plethora of literature on multiculturalism and on interculturalism, the fact is that, in Portuguese schools, some students still seem to be shaped and limited by their cultural background and it is up to us, as teachers, to prepare children for this contemporary globalised world. But education is much linked to the ideology of the ruling elites and is political at every stage. The textbook publishing industry, following a selective curriculum, is proof of the perpetuation of the status quo, because school materials have sometimes ignored and marginalised peoples seen as the "Other".

In this light, time has come for us to analyse the way that textbooks have adopted and adapted to the government's recent policies, the so called Metas Curriculares, namely in the treatment of a literary corpus. We will direct our particular attention to textbooks that address Mia Couto's $O$ beijo da palavrinha and $O$ gato e o escuro to check if activities relating to the texts of this Mozambican writer do promote tolerance and acceptance of differences or if they are marked by ignorance and prejudice.
\end{abstract}

Key Words: Literature of Portuguese-speaking countries for children and young adults, textbooks, curriculum, identity, representation/perception, difference.

$* * * * *$

\section{Introduction, motivation and methodology}

This brief essay presents and discusses some parts of an ongoing Master's project entitled 'Papel dos manuais escolares de português na promoção de valores 
da interculturalidade no $1 .{ }^{\circ}$ Ciclo do Ensino Básico, ${ }^{1}$, conducted at the School of Education at the Polytechnic Institute of Viseu.

The motivation behind this study emanates from a desire to understand the importance of textbooks in shaping children's perceptions of themselves, of the Other and the world around them. In particular, and bearing in mind that we are living in a time of breaking down barriers and crossing over boundaries, a time in which economic integration, migration of peoples and technological developments are leading us inexorably towards a global village, we intend to analyse the way that textbooks can be a means of imparting civic and democratic values, in accordance to the Portuguese Decree-Law no. 14788-A/2013 of 14 November 2013. In fact, this legal document declares that textbooks must fulfil state educational requirements, namely in regards to a unified national curriculum and national syllabi, while integrating citizenship education as a cross-disciplinary dimension and respecting the values and fundamental rights and duties, as defined in the Constitution.

Aware, as we are, of the difficulties in taking up such a time-consuming and exhaustive endeavour in a semester that may not be entirely dedicated to research work, and, on the other hand, because the class that was available to participate in this study is a fourth grade from a determined Primary School in Viseu, we decided to restrict the project to a case study. We chose two texts by the Mozambican writer Mia Couto, $O$ beijo da palavrinha and $O$ gato e o escuro, as they are part of the mandatory reading list for fourth-graders and also because they fit perfectly our intents of examining the perspective of children on a range of issues associated with interculturalism and respect for one's differences. Moreover, we want to analyse the way that textbooks portray these differences, which means that we will have to check if activities relating to Couto's texts are biased in any way, influencing students.

In terms of methodology, it is important to state that, besides the above mentioned analysis of textbooks, an inquiry is being used to take the study beyond the texts. By this, we mean that we intend to scrutinise children's representations of 'the Self' and 'the Other', because the values of tolerance, inclusiveness and critical thinking need to be taught from a tender age. Today's children are tomorrow's adults and they will be living in a society that will be even more global than it has been so far. As Bizarro points out:

Numa sociedade marcada pela pluralidade (linguística, ideológica, étnica, educacional, ...), na qual irrompe com inequívoca força o desafio para se (re)construir um agora em que todos se sintam iguais, permanecendo diferentes, urge compreendermos o Eu e o Outro como a possibilidade de concretização real do estabelecimento de laços interculturais e de diálogos que ajudem à inter/compreensão quer dos indivíduos de 
per si quer da sociedade e que viabilizem o verdadeiro desenvolvimento humano e social. ${ }^{2}$

Thus, we will ask children to answer two questionnaires, one before a course unit on one of the texts by Mia Couto is lectured, and the other afterwards, so that we may understand if, by any means, textbooks combined with the teacher's action may influence the perceptions and attitudes of students towards Otherness and the world's pluralism and, if so, in what way.

\section{Curriculum and the role of textbooks}

It is an undeniable fact that, during the years of schooling, textbooks function as an important vehicle for imparting information to students and improving language skills, while, simultaneously, transmitting socially shared values and rules. They may be regarded as silent teachers for those who read them and we may say that, to a great extent, teachers themselves rely a lot on these resources, since they base their lessons on them. On this issue, Patrick Shannon argues that '[a]ccording to critical educators, technical control of schooling through textbooks "deskills" the teachers who use them, , because they are expected to follow specific directions, which sometimes means that they are left with no control in the conceptualisation of teaching action, to become eventually 'reskilled' as managers of the didactic resources available to them.

Whether the use of textbooks may be looked at with suspicion, as a limiting approach to the curriculum - an approach that is helpful for poorly prepared teachers, some say - or, on the other hand, as a positive strategy for unifying and improving teaching, the truth is that this market forms an essential component in the educational system, as it is responsible for transmitting selected knowledge from one generation to the next. The textbook industry is given a legitimised voice in putting forward what is to be taught when it determines the content of its publications, obviously bearing in mind support documents issued by the Ministry of Education, such as the National Curriculum Guidelines of Portuguese in Elementary Education, issued in 2009, and the Common Core State Standards for Portuguese (CCSSP), enacted in August 2012.

As Apple points out,

[t]he curriculum is never simply a neutral assemblage of knowledge, somehow appearing in the texts and classrooms of a nation. It is always part of a selective tradition, someone's selection, some group's vision of legitimate knowledge. ${ }^{4}$

In Portugal, not only the Government - or, to be precise, the Boards of Education elected by the Ministry of Education - selects what is to be studied, but Publishing companies also exert an enormous influence on the instruction and 
education of students, as they produce textbooks to support the Programme and to assist teachers. Publishing companies decide which texts, among a defined literary corpus, are to be read and, afterwards, they design activities of reading, writing, grammar and speaking based on such prescribed texts. Teachers are, then, the ultimate arbiters of what is to be covered in class and how. However, in spite of each teacher's individual emphasis, the fact is that resource guides, multimedia materials (PPT presentations, CD-ROMs, films, interactive games, ...) and the deconstruction of the texts that is inherent to follow-up activities frequently make the task of getting around possible biases more complicated.

\section{The importance of values in the evaluation process for textbook certification}

Fortunately, nowadays, biases are less likely to occur in textbooks in Portugal, due to the efforts brought by the aforementioned Portuguese Decree-Law no. 14788-A/2013 of 14 November 2013, which establishes the following criteria for use in the evaluation process for textbook certification: 1. Linguistic, scientific and conceptual accuracy; 2. Compliance with a national curriculum and national standards; 3. Pedagogical and didactic quality; 4. Values; 5 . Re-use and minimal adequacy period of six years; 6 . Material quality, namely its robustness and weight.

Let us focus, then, on the requirement number four, especially on its subparagraph (b), which clearly states that textbooks must respect the fundamental values, rights and duties as defined in the Constitution.

'Whose values, rights and duties?', we may ask. In a world that is rapidly becoming more culturally diverse, we need to respect not only those who do not look like us in terms of colour or place of birth for instance, but also those who do not share our beliefs and our worldviews. There are other differences besides the most obvious ones, profound differences that we must take into account in every intercultural encounter, if we want the key to a peaceful world. According to the UNESCO world report,

Regarding peace and conflict prevention, acknowledging cultural diversity plays emphasis on 'unity in diversity', the shared humanity inherent in our differences. Far from representing a potential restriction on universally proclaimed human rights, cultural diversity furthers their effective exercise, strengthens social cohesion and provides sources of inspiration for renewing forms of democratic governance. ${ }^{5}$

In Portugal, schools are becoming more and more pluralistic with regard to race, religion and socio-economic respects. The Ministry of Education/Department of Elementary Education, well aware of the need to promote Intercultural Education, has recently launched guidelines for civics and citizenship education, 
which include, among others, the following dimensions: education for gender equality, education for human rights and intercultural education. The latter intends to promote the recognition and value of diversity as an opportunity and as a source of knowledge for all, with due respect for contemporary societies. The aim is to develop skills such as the ability to communicate and to encourage social interaction, creating identities and sharing a common sense of humanity ${ }^{6}$.

In spite of such noble aim, and as UNESCO reminds us,

Textbooks can reinforce stereotypes and perpetuate discrimination. For example, language-teaching materials can surreptitiously provide misleading and simplistic interpretations of other cultures. When curriculum or textbooks content explicitly or implicitly disparages some social groups, schools can inculcate intolerance and reinforce social divisions. While schools have the potential to provide a peaceful environment in which children learn and interact with each other, they can also play a role in normalizing violence, and in undermining attitudes conducive to peaceful conflict resolution. ${ }^{7}$

\section{Analysis of corpora: a synopsis of the work in progress}

It is in the attempt to provide a space for intercultural dialogue that Portuguese children read and analyse texts by writers of both national and foreign countries. Two of the texts that interest us here are from Mozambique, a Portuguese speaking country and one of the former Portuguese colonies, together with Angola, Cape Verde, Guinea Bissau, Brazil, among others. The Mozambican writer is a white male from the city of Beira and he has been the recipient of several honours and awards, namely the Award Vergílio Ferreira (1999), the Award Camões (2013) and the Neustadt International Prize for Literature (2014).

In Couto's books for children, this Mozambican writer successfully blends African oral tradition with Portuguese narrative style, creatively manipulating the Portuguese language, reinventing reality in a fluid interplay of fantasy and verisimilitude, and taking the reader to an unexpected representation of multifaceted identities and fragmented views of self-perception.

Particularly, the two texts under consideration, $O$ beijo da palavrinha and $O$ gato e o escuro, are stories that overcome boundaries of time, geography, religion, gender and age, enabling a cultural dialogue and opening up a shared moral universe of meaning, as both deal with issues of change and difference, in all its forms.

In the first narrative, we get to know Maria Poeirinha, a poor girl whose life is so hard that she eventually becomes ill and dies. Her name alone ${ }^{8}$ allows readers to expect a fragile girl living a life of misery and emptiness in an inland village of Mozambique, and yet she rejoices in the assurance of hope when her uncle 
Litorânio - from litoral, that is, 'coastline', evoking the great force and abundance of waters, as opposed to the dryness of the land where they all live - suggests the sea as a healing space, a therapy that proves to be impossible because the protagonist is too weak to embark on any journey. It is her brother Zeca Zonzo, a young fellow deprived of good sense and judgement', , who decides to write the word 'SEA' on a piece of paper and helps her go through every letter with her finger. The written word acquires then a transformative force and takes the girl to a dimension of spiritual release and freedom from all the evils brought about by her disease. Maria Poeirinha embodies a seagull and departs towards the unknown, letting us be touched by the power of language (or according to the very title of the story, letting us be kissed by this three letter word).

Change, difference and acceptance are also keywords in $O$ gato e o escuro, an appealing narrative for children in which Pintalgato, a yellow tigered and spotted tomcat, disobeys his mother and goes beyond the border of the day and light, suffering the consequences of his curiosity: a fright turns his fur into black, darker than the gloomiest shade of night. This darkness is feared and hated by Pintalgato, until he discovers an Other that is the Dark himself and that is rescued, adopted and nurtured back to light by Pintalgato's mother. Ultimately, Pintalgato finds out that the episode experienced had been but a dream and he realises that the dark exists only within us, in our imagination, and that the fear we feel towards to unknown creates walls that block out the light.

These two books by Mia Couto promote an encounter with the Other whom we don't know and fear so often. They promote a dialogue in favour of plurality and academic change, which is, after all, the ethos of interculturalism, as Maxine Greene makes clear:

Changing demographies and the new immigrations are making the phenomenon of pluralism inescapable in this [world]. At once, what is recognized as an erosion of community requires us to find ways of reconciling a newly acknowledged diversity with a Deweyan notion of a 'Great Community' (...) heeding multiple voices silenced over the years, (...) making them part of the ongoing 'conversation' that distinguishes our culture. This entails an incorporation of visions seldom tapped before; it entails a recognition of exclusions and deficiencies long denied, a discovery of ways to fill the voids and in some fashion to repair. Finally, seeking a regard for distinctiveness as well as a reaching toward connectedness, [interculturalism provides] opportunities for concrete engagements, for imaginative efforts to cross the distances and look through diverse others' eyes. ${ }^{10}$ 
It is a pity that in $O$ Mundo da Carochinha the reading comprehension activities concerning the short story $O$ gato e o escuro show no efforts to address the issue of difference and to create 'opportunities for concrete engagements', as noted by Greene. From our point of view, the follow-up tasks related to the text call for a literal interpretation, except for the second question, which asks "Atenta na frase: "Somos nós que enchemos o escuro com os nossos medos". Concordas com esta afirmação da mãe gata? Justifica a tua resposta' ${ }^{11}$, and the fourth one which questions 'A que conclusão chegou Pintalgato quando acordou?'12. These two are the only ones that help develop critical thinking, a skill that is emphasised by Giroux when he states:

If educators are to take the relationship between schooling and democracy seriously, this means organizing school life around a version of citizenship that educates students to make choices, think critically, and believe that they can make a difference. ${ }^{13}$

An uncritical approach that merely avoids biased material does not ask for a critical eye and, therefore, does not imply the ability to engage critically in the world, believing that change is possible. In our opinion, O Mundo da Carochinha could make better use of Couto's text in order to offer children the possibility to involve themselves in the process of reframing difference.

On the other hand, Alfa 4 allows students to respect difference through the reading of excerpts from $O$ beijo da palavrinha, as, on page 113, it invites them to think about ways in which they could solve Maria Poeirinha's problem: ' $\ldots$ De que forma é que tu mostrarias o mar à menina doente, que não podia viajar?' ${ }^{14}$ or 'Será que Maria Poeirinha venceu a doença?' ${ }^{15}$ It also encourages them to recognise linguistic differences between these two Portuguese-speaking countries: 'Mia Couto (...) é moçambicano e escreve em português. Pede ajuda ao teu professor e identifica algumas expressões que não são comuns no português de Portugal ${ }^{16}$.

Bearing in mind the Common Core State Standards for Portuguese, and paying particular attention to the goal EL4.25.2 - Manifestar sentimentos e ideias suscitados por histórias e poemas $\operatorname{lidos}^{17}$-, we believe that textbooks should promote children's critical thinking, their moral reaction to human experience and the articulation of this all with both the power of storytelling and with personal knowledge.

\section{Final remarks}

In conclusion, we have just briefly come across two examples of textbooks for fourth-graders that deal with issues of difference and, even though this project is far from being complete, we may already anticipate that these two resources - and textbooks in general - may be used to promote intercultural coexistence. Even those textbooks which avoid 'bringing up potentially contentious issues in the 
curriculum in fear that doing so may create or exacerbate animosity and hostility among students', in Neito's words ${ }^{18}$, include literary texts that enable the opportunity for dialogue and, hopefully, an appropriate treatment of diversity. However, we cannot expect textbooks to do it all, as Giroux makes clear when he writes that the most important is the creation of opportunities for the exchange of ideas and of experiences:

educators [and not only textbooks] need to offer students the opportunities to explore cultural difference in historical and contextual terms that open up rather than shut down partiality, possibilities, and dialogue. As border crossers, students must engage knowledge as citizens of the world. ${ }^{19}$

As our closing remarks, we believe it is worthwhile mentioning that this study has been helpful in making us realise that intercultural education is a very complex and multidimensional phenomenon that requires the cooperation of multiple actors for goal attainment.

\section{Notes}

1 'The role of textbooks of Portuguese language in the promotion of intercultural values in Primary School'.

${ }^{2}$ R. Bizarro (Org.), Eu e o Outro: Estudos multidisciplinares sobre Identidade(s). Diversidade(s) e Práticas Interculturais. Porto, Areal Editores, 2007, p. 7.

${ }^{3}$ P. Shannon, The struggle to continue: Progressive reading instruction in the United States, Heinemann, Portsmouth, NH, 1990, p. 153.

${ }^{4}$ M. Apple, Cultural politics and education, Teacher College Press, New York, 1996, p. 22.

5 UNESCO, World report: investing in cultural diversity and intercultural dialogue, United Nations Educational, Scientific and Cultural Organization, Paris, 2009, p. 251.

${ }^{6}$ Direção-Geral da Educação, Educação para a Cidadania: Linhas Orientadoras, Ministério da Educação, Lisboa, 2012, p. 5.

7 UNESCO, Teaching respect for all: implementation guide, United Nations Educational, Scientific and Cultural Organization, Paris, 2014, p. 113.

${ }^{8}$ Maria Poeirinha is translated into English as 'Mary Dusty'.

${ }^{9}$ M. Couto, O beijo da palavrinha, Editorial Caminho, Alfragide, 2008, p. 16.

${ }^{10} \mathrm{M}$. Greene, 'The passions of pluralism: Multiculturalism and the expanding community', Educational Researcher, 22, 1993, p. 13. 
${ }^{11}$ C. Letra \& M. Borges, O Mundo da Carochinha, Português Gailivro 4, Edições Gailivro, Alfragide, 2013, p. 71.

Our translation: [Look closely at the sentence: 'We are the ones who fill the dark with our fears'. Do you agree with the mother cat's statement? Justify your answer].

${ }^{12}$ Ibid.

Our translation: [What was the conclusion that Pintalgato reached when he woke up?].

${ }^{13}$ H. Giroux, 'Educational visions: What are schools for and what should we be doing in the name of education?' Kincheloe and Steinberg (eds.). Thirteen questions: Reframing education's conversations, Peter Lang, New York, 1996, p. 298.

14 E. Lima, N. Barrigão, N. Pedroso \& V. Rocha, Alfa 4 - Português, Porto Editora, Porto, 2013, p. 113.

Our translation: [In which way would you show the sea to the diseased girl, who could not travel?].

${ }^{15}$ Ibid.

Our translation: [Do you think that Maria Poeirinha could beat her disease?].

${ }^{16}$ Ibid.

Our translation: [Mia Couto (...) is Mozambican and writes in Portuguese. Ask for your teacher's help to identify some expressions that are uncommon to Portuguese from Portugal].

${ }^{17}$ Our translation: [To express feelings and ideas inspired by stories or poems read].

18 S. Neito, 'Lessons for students on creating a chance to dream', Harvard Educational Review, 64 (4), 1994, p. 403.

${ }^{19}$ H. Giroux, p. 299.

\section{Bibliography}

Apple, M., Cultural politics and education, Teacher College Press, New York, 1996.

Bizarro, R. (Org.), Eu e o Outro: Estudos multidisciplinares sobre Identidade(s).

Diversidade(s) e Práticas Interculturais. Porto, Areal Editores, 2007.

Couto, M., O beijo da palavrinha, Editorial Caminho, Alfragide, 2008. , O gato e o escuro. Editorial Caminho, Alfragide, 2001.

Direção-Geral da Educação, Educação para a Cidadania: Linhas Orientadoras. Ministério da Educação, Lisboa, 2012.

Giroux, H., 'Educational visions: What are schools for and what should we be doing in the name of education?' Kincheloe and Steinberg (eds.). Thirteen 
questions: Reframing education's conversations, Peter Lang, New York, 1996, pp. 295-304.

Greene, M., 'The passions of pluralism: Multiculturalism and the expanding community', Educational Researcher, 22, 1993, pp. 13-18.

Letra, C. \& Borges, M., O Mundo da Carochinha, Português Gailivro 4, Edições Gailivro, Alfragide, 2013.

Lima, E., Barrigão, N., Pedroso, N. \& Rocha, V., Alfa 4 - Português, Porto Editora, Porto, 2013.

Neito, S., 'Lessons for students on creating a chance to dream', Harvard Educational Review, 64 (4), 1994, pp. 392-426.

$\mathrm{P}$. Shannon, The struggle to continue: Progressive reading instruction in the United States, Heinemann, Portsmouth, NH.

UNESCO, World report: investing in cultural diversity and intercultural dialogue, United Nations Educational, Scientific and Cultural Organization, Paris, 2009.

UNESCO, Teaching respect for all: implementation guide, United Nations Educational, Scientific and Cultural Organization, Paris, 2014.

Susana completed her PhD in the field of Children's Literature in 2011 and she is working as an Invited Adjunct-Professor in the Language Sciences Department at the School of Education, Polytechnic of Viseu. She is a member of the Centre for the Study of Education, Technologies and Health at the same institute and her areas of interest include CanLit, (Portuguese) Children's Literature \& Creative Writing.

Sara Pinho holds a bachelor's degree in Elementary Education and she is currently pursuing a master's degree in Early Childhood and Primary Education, at the School of Education, Polytechnic Institute of Viseu. In September 2014, she presented her first paper as part of an international event - II JOEEL - entitled "Space and recognition of the Other in texts by Mia Couto".

João Paulo Balula holds a PhD in Didactics. He is Vice-President of the School of Education, Polytechnic of Viseu, a member of the Centre for the Study of Education, Technologies and Health at the same institute and Coordinator Professor in the Language Sciences Department. His main research interests are the development of lifelong reading habits and education for global citizenship. 